\title{
KARAKTER RAJIN (RELIGIUS, AKTIF, JUJUR, INOVATIF DAN NASIONALIS) DALAM KITAB SYI'IR NGUDI SUSILO KARYA K.H BISRI MUSTOFA) MENUJU GENERASI KHAIRA UMMAH
}

\author{
MUSTAQHFIRIN \\ SMPN 2 Penawangan Kab. Grobogan Prov. Jawa tengah \\ E-mail : mfirin5@gmail.com
}

\begin{abstract}
ABSTRAK
Konsep pendidikan karakter dari Syi'ir Ngudi Susilo karya KH Bisri Mustofa, dapat diterapkan dalam kehidupan sehari-hari, karena relevansi tujuan Pendidikan Nasional. Penelitian ini merupakan penelitian kepustakaan (library research), suatu penelitian yang bertujuan mengumpulkan data dan informasi dengan bantuan bermacam-macam material yang terdapat di ruang perpustakaan, metode pengumpulan data dilakukan dengan menggunakan sumber karya tulis kepustakaan, analisis data yang digunakan reduksi data, penyajian, kesimpulan dengan pendekatan kualitatif untuk menganalisis, menggolongkan, mengorganisasi data, sehingga kesimpulan dan verifikasi dapat dilakukan. Hasil penelitian menujukkan bahwa konsep pendidikan karakter dalam kitab Syi'ir Ngudi Susilo sangat relevan dengan tujuan pendidikan Nasional, Karakter RAJIN (Religius, dengan membiasakan anak melaksanakan perintah Allah SWT. Aktif, dengan pembiasaan membagi waktu antara bermain dan belajar, peduli pada lingkungan dengan menjaga kebersihan dan kerapian. Jujur dalam berperilaku sebagai modal tercapainya kemuliaan, kejujuran menuntun kearah keselamatan. Inovatif memiliki gagasan dan ide-ide baru untuk mencapai kemaslahatan hidup, tidak mudah menyerah dan berputus asa harus memiliki cita-cita luhur dan sejati. Nasionalis, menanamkan rasa cinta tanah air dan peduli terhadap masa depan bangsa, pemuda sekarang adalah pemimpin masa depan) sehingga terwujud generasi Khaira Ummah
\end{abstract}

Kata Kunci: Karakter, Rajin, Ngudi Susilo

\section{PENDAHULUAN}

Islam merupakan agama yang membawa misi pada pembentukan karakter yang baik dan mulia pada umat manusia. Pembinaan nilai sebagai bagian yang tak terpisahkan dari pendidikan dapat menjadi sarana ampuh dalam menangkal pengaruh-pengaruh negatif, baik pengaruh yang berasal dari dalam negeri maupun luar negeri. Pendidikan merupakan pusat atau pokok dari peradaban dalam kehidupan ini, penciptaan manusia oleh Allah SWT sebagai khalifahnya tidak bisa lepas dari pendidikan yang merupakan tolak ukur dari berhasil atau tidaknya peran manusia menjadi khalifah di dunia ini. Tujuan pendidikan Nasional Indonesia, dalam UU no 20 tahun 2003 tentang Sistem Pendidikan Nasional adalah untuk berkembangnya potensi peserta didik, agar menjadi manusia yang beriman dan bertaqwa kepada Tuhan Yang Maha Esa, berakhlak mulia, sehat, berilmu, cakap, kreatif , madiri, dan menjadi warga negara yang demokratis serta bertanggung jawab.

Bangsa Indonesia saat ini, tidak hanya mengalami proses pendangkalan nilai, yang seharusnya dimiliki serta dihayati dan dijunjung tinggi. Nilai-nilai tersebut telah bergeser dari kedudukan dan fungsinya serta digantikan oleh keserakahan, ketamakan, kekuasaan, kekayaan dan kehormatan. Keluarga memiliki peranan penting dalam pembentukan karakter anak, karena pendidikan yang kali pertama didapatkan anak adalah pendidikan keluarga, orang tua sebagai figur utama dalam pembentukan karakter anak, sejak kecil ia bersama orang tua, melihat prilaku yang dilakukan orang tua, apabila orang tua berprilaku baik anak akan cenderung berprilaku baik, dan sebaliknya, karena anak adalah peniru yang cerdas.

KH. Bisri Mustofa, merupakan satu di antara ulama Islam Indonesia, yang peduli dalam perbaikan moral masyarakat, beliau dikenal sebagai orator yang mampu mengutarakan hal-hal yang sebenarnya sulit menjadi mudah diterima semua kalangan baik orang kota maupun desa, sesuatu yang berat menjadi ringan, yang membosankan menjadi mengasyikkan, yang 
kelihatannya sepele menjadi amat penting. Kritikannya sangat tajam meluncur dengan lancar dan menyegarkan, pihak yang terkena kritik tidak marah karena disampaikan secara sopan dan menyenangkan, kemampuanya berpidato mampu menyedot emosi para pendengarnya dengan tuntas, terhanyut dalam cerita/kisah yang dibawakanya.

KH. Bisri Musthofa banyak menyusun karya-karyanya dalam bentuk kitab-kitab, diantaranya kitab Syi'ir Ngudi Susilo merupakan karya tulis yang banyak bersentuhan dengan dunia pendidikan. Syi'ir ini berisikan tentang pesan - pesan moral yang ditujukan bagi anakanak tentang tata cara menghormati dan berbakti kepada orang tua (Birrul Walidain)(Zainal Huda : 2005). Karya ini menurut pengamatan peneliti, belum banyak yang mengkaji dan menggali tentang nilai-nilai pendidikan karakter anak yang terkandung didalamnya. Kitab ini banyak dipergunakan diberbagai Madrasah Diniyah (Madin) atau "Sekolah Arab/Sore", dinamakan sekolah sore karena kebanyakan madrasah ini dilaksanakan pada sora hari setelah sekolah formal pagi hari, sebagai pengenalan akhlak dan budi pekerti yang dikemas dengan bahasa yang mudah difahami, menggunakan bahasa jawa dan berhuruf arab pegon, berisi tentang budi pekerti atau akhlak yang ditulis pada tahun $1954 \mathrm{M} / 1373 \mathrm{H}$, yang kemudian diterbitkan oleh penerbit Menara Kudus.

Akhlak mulia merupakan tujuan utama diutusnya Nabi Muhammad SAW yang dikuatkan dalam sebuah hadis yang diriwayatkan oleh Abu Hurairah r.a. "Sesungguhnya aku diutus hanya untuk menyempurnakan akhlak (budi pakerti/karakter) yang mulia" H.R Al Baihaq. Pudarnya nilai Religiusitas dapat dilihat dengan banyaknya ummat yang meninggalkan ibadah kepada Allah SWT, banyak dijumpai generasi muda yang larut dalam perbuatan yang bertentangan dengan norma agama maupun negara, tidak memanfaatkan waktu untuk sesuatu yang berguna, tertangkapnya para pejabat yang koruptor menunjukkan pudarnya kejujuran dan tanggungjawab dalam melaksankan tugas dan kewajibanya mengakibatkan terjadinya kerugian negara, manusia dituntut untuk mengembangkan pemikiranya agar tercapai kebahagiaan hidup didunia dan akhirat, dibutuhkan berbagai setrategi agar manusia mmampu menunjukkan esensinya sebagai kholifah dibumi, menipisnya rasa cinta pada negeri akan berakibat sikap acuh tak acuh terhadap nasib bangsa dan negara, hilangnya kepedulian kepada sesama, munculnya sikap indivudualis yang menuntun pada liberalisme.

Situasi dan kondisi karakter bangsa yang sedang memprihatinkan, mendorong pemerintah untuk mengambil inisiatif untuk memprioritaskan pembangunan karakter bangsa, Pembangunan karakter bangsa dijadikan arus utama pembangunan nasional, yang berarti bahwa setiap upaya pembangunan harus selalu diarahkan untuk memberi dampak positif terhadap pengembangan karakter (Zubaidi, 2011). Atas dasar berbagai pemikiran tersebut, peneliti memandang perlu untuk mengangkat sebuah penelitian dengan judul " Karakter RAJIN (Religius, Aktif, Jujur, Inovatif dan Nasionalis) dalam kitab Syi 'ir ngudi susilo Karya KH Bisri Mustofa " agar terwujud Khaira Ummah menuju generasi yang bahagia dunia dan akhirat.

\section{METODE PENELITIAN}

Penelitian ini adalah penelitian pustaka, maka metode pengumpulan data dilakukan dengan menggunakan metode pengumpulan data library research (Hadi sutrisno:1997) yang mengandalkan atau memakai sumber karya tulis kepustakaan. Metode ini penulis gunakan dengan jalan membaca, menelaah buku-buku dan artikel yang berkaitan dengan tema penelitian ini. Penelitian kepustakaan (library research), merupakan suatu penelitian yang bertujuan untuk mengumpulkan data dan informasi dengan bantuan bermacam-macam material yang terdapat di ruang perpustakaan, seperti buku-buku, majalah, naskah-naskah, catatan, kisah sejarah, dokumen-dokumen dan sebagainya.(Kartono:1996)

Sumber data yang dipergunakan 1) Data primer yang dimaksud merupakan karya yang langsung diperoleh dari tangan pertama yang terkait dengan tema penelitian ini. jadi data-data primer ini merupakan karya dari K.H Bisri Mustofa yaitu kitab Syi'ir Ngudi Susilo. 2) Data 
sekunder diambil dari beberapa tulisan yang terkait dengan KH Bisri Mustofa. Data yang diperoleh tersebut dipergunakan untuk menyusun dan menganalisa data-data yang terkumpul dengan metode Deskriptif-Analitik. Metode deskriptif-analitik ini akan gunakan untuk melakukan pelacakan dan analisa terhadap pemikiran, biografi dan kerangka metodologis pemikiran K.H Bisri Mustofa. dengan cara menganalisis data yang diteliti dengan memaparkan data-data tersebut kemudian diperoleh kesimpulan. (Arikunto, 2002).

Analisa data yang dilakukan dalam penelitian ini pada dasarnya merupakan proses pengorganisasian dan mengurutkan data ke dalam kategori dan satuan uraian dasar sehingga dapat ditemukan pola, tema yang dapat dirumuskan sebagai hipotesa kerja. Data yang diperoleh dari lapangan/pustaka jumlahnya cukup banyak, untuk itu perlu dicatat secara teliti dan rinci, mereduksi data berarti merangkum, memilih hal-hal yang pokok, menfokuskan pada hal-hal yang penting, dicari tema dan polanya dan membuang yang tidak perlu, Reduksi data dipergunakan untuk mempertajam analisis data, menggolongkan, membuang yang tidak perlu dan mengorganisasi data, sehingga kesimpulan dan verifikasi dapat dilakukan. Tujuan pengorganisasian dan pengolahan data tersebut adalah untuk menemukan tema dan hipotesa kerja yang akhirnya diangkat menjadi teori. (Saidi, 2017)

Hasil analisis yang dilakukan diharapkan akan mempunyai sumbangan teoritik, yang mengarah pada interpretatif, yang berarti juga akan bersinggungan dengan kajian hermeneutik Hermeneutika secara umum didefinisikan sebagai suatu teori atau filsafat tentang interpretasi makna. Kata hermeneutika sendiri berasal dari kata kerja Yunani Hermeneuien yang memiliki arti menafsirkan, menginterpretasikan atau menerjemahkan (Athol, 2003). pendekatan hermeneutika akan digunakan sebagai pisau analisis untuk membedah konstruksi pemikiran K.H Bisri Mustofa dalam bidang Pendidikan Akhlak. pengumpulan data dilakukan dengan metode dokumentasi hasil karya KH Bisri Mustofa dan Buku penelitian lainnya.

\section{PEMBAHASAN}

\section{Pendidikan Karakter Anak}

Kamus Besar Bahasa Indonesia mengartikan pendidikan adalah proses pengubahan sikap dan tata laku seseorang atau kelompok orang dalam usaha mendewasakan manusia melalui upaya pengajaran dan pelatihan, proses, cara, perbuatan mendidik, Marimba menyatakan bahwa pendidikan adalah bimbingan atau pimpinan secara sadar oleh pendidik terhadap perkembangan jasmani dan rohani anak didik menuju terbentuknya kepribadian yang utama. (Tafsir, 2011:14).

Karakter berasal dari bahasa Yunani karasso yang berarti cetak biru, format dasar, atau sidik seperti dalam sidik jari. Pendapat lain menyatakan berasal dari kata charassein yang berarti membuat tajam atau membuat dalam. Sedangkan karakter menurut Kamus Besar Bahasa Indonesia berarti sifat-sifat kejiwaan, akhlak atau budi pekerti yang membedakan seseorang dari yang lain, tabiat, watak (Saptono, 2011:17-18). Dari pengertian tentang pendidikan dan karakter di atas dapat dipahami bahwa pendidikan karakter merupakan serangkaian usaha yang dilakukan secara sadar dan terencana sehingga memunculkan kesadaran dalam diri individu untuk mengembangkan segala potensi manusia sehingga memiliki kekuatan spiritual, kecerdasan, dan akhlak mulia menuju kedewasaan dan kesempurnaan sebagai bekal yang diperlukan dalam menjalani kehidupan bermasyarakat, berbangsa, dan bernegara.

Anak didefinisikan sebagai seorang yang dilahirkan dari perkawinan antar seorang perempuan dan seorang laki-laki, anak adalah aset bangsa, masa depan bangsa berada ditangan anak sekarang, semakin baik kepribadian anak sekarang maka akan semakin baik pula masa depan bangsa, demikian pula sebaliknya apabila kepribadian anak sekarang buruk maka akan buruk pula masa depan bangsa. (Marliani, 2016:40)

Faktor utama yang mempengaruhi perkembangan anak dan remaja diantaranya adalah heraditas yang diperoleh dari orang tuanya, selain itu lingkungan merupakan faktor penting yang menentukan perkembangan individu, meliputi lingkungan fisik, psikis, sosial dan 
religius. lingkungan yang baik akan berpengaruh baik terhadap perkembangan anak dan remaja, demikian pula sebaliknya. Fase anak-anak awal adalah masa perkembangan yang berlangsung sejak akhir masa bayi sampai 5 atau 6 tahun, yang sering disebut masa pra sekolah, fese anak-anak tengah dan akhir adalah fase perkembangan yang berlangsung sejak umur 6 sampai 11 tahun atau masa sekolah dasar. (Marliani, 2016:140).

Kerangka Pemikiran dalam penelitian ini meliputi : Pertama Komponen input analisis mencakup 3 fenomena yaitu : 1) belum banyaknya penelitian yang dilakukan terhadap Pemikiran-pemikiran para Ulama dan Tokoh Nasional yang telah mencurahkan pemikiranya untuk mencerdaskan anak bangsa. 2) belum sepenuhnya orang tua menyadari dan berperan aktif dalam pembentukan karakter terutama masyarakat yang berpendidikan rendah, hanya menitikberatkan pada proses pembelajaran disekolah, 3) Degradasi moral Generasi muda dari berbagai sisi kehidupan meliputi, rendahnya kesadaran dan ketaatan beragama, berkurangnya keaktifan dan kepedulian dalam kebaikan, berkurangnya kejujuran dalam ucapan dan tindakan, kurangnya kreatifitas dan inovasi dalam berkarya, dan rasa cinta terhadap bangsa dan negara (nasionalisme) yang rendah, hal inilah yang mendorong peneliti untuk menganalis konsep pemikiran beliau, dengan teori-teori yang menjadi rujukan penyusunan konsep operasional variabel penelitian, yaitu teori pendidikan karakter

Kedua Berdasarkan input analisis yang demikian dilakukan proses analis data yang terkumpul dengan metode Deskriptif analitik, dan dipertajam dengan content analysis (analisis isi) yang penulis gunakan untuk melakukan pelacakan dan analisa terhadap pemikiran, biografi, dan metode pemikiran Pendidikan Karakter anak oleh K.H Bisri Mustofa dalam Kitab Syi'ir Ngudi Susilo, dengan tujuan pendidikan Nasional untuk mewujudkan generasi Khaira Ummah

Ketiga Output Analisis adalah pokok-pokok kesimpulan dan saran, bahwa dalam kitab Syi 'ir Ngudi Susilo terkandung nilai-nilai pendidikan karakter Religius, Aktif, Jujur, Inovatif dan Nasionalis yang di rangkum dalam kata RAJIN. Dengan kerangka pemikiran tersebut, maka diasusmsikan bahwa melalui Konsep, ide, gagasan dan pemikiran K.H Bisri Mustofa dalam kitab Syi'ir Ngudi Susilo yang dapat di implementasikan dalam penguatan pendidikan karakter anak baik dalam keluarga, sekolah dan masyarakat, agar tercapai tujuan pendidikan nasional sebagaimana yang tercantum dalam UU no 20 Tahun 2003 dan terwujudnya Generasi Khaira Ummah

Beliau dilahirkan pada tahun $1915 \mathrm{M}$ atau bertepatan tahun $1334 \mathrm{H}$. di kampung Sawahan Gang Palen Rembang Jawa Tengah. Beliau adalah anak dari pasangan suami istri H. Zainal Mustofa dan Khatijah yang telah memberinya nama Mashadi (Syaifullah Maksum ,1998:319). Pada tahun 1923 Mashadi diajak oleh bapaknya untuk ikut bersama- sama sekeluarga menunaikan rukun Islam yang kelima, saat menunaikan ibadah haji tersebut $\mathrm{H}$. Zainal Mustofa sering sakit-sakitan. Sampai menginap wukuf di Arafah, menginap di Mina, Tawaf dan Sa'i juga dalam keadaan sakit. Sehingga beliau harus ditandu. Selesai ibadah haji dan hendak berangkat ke Jeddah untuk pulang ke Indonesia, H. Zainal Mustofa dalam keadaan sakit keras, saat sirine kapal berbunyi sebagai tanda kapal akan segera berangkat, Allah SWT memanggil nya dalam usia 63 tahun. Jenazahnya diserahkan kepada seorang Syekh untuk ongkos dan sewa tanah pemakaman, sehingga keluarga tidak tahu di mana makam almarhum H. Zainal Mustofa. Sejak pulang dari ibadah haji Mashadi mengganti namanya dengan nama Bisri (sindicate, 2006:4), kemudian akrab dengan sebutan Bisri Mustofa.

Pada tahun 1925 Bisri Mustofa bersama-sama dengan H. Muslich (Maskub) oleh kakaknya H. Zuhdi diantar ke Pondok Pesantren Kajen, pimpinan Kyai Chasbullah untuk mondok bulan puasa. Baru tiga hari ia tidak kerasan. Dan pulang kembali ke Rembang, setelah lulus sekolah di Ongko 2 pada tahun 1926 Bisri Mustofa diperintah oleh H. Zuhdi untuk turut mengaji dan mondok pada kyai Cholil Kasingan. Pada awalnya Bisri Mustofa tidak minat belajar di Pesantren. Sehingga hasil yang dicapai dalam awal-awal mondok di Pesantren Kasingan sangat tidak memuaskan. (Zaenal, 2005:11) 
Permulaan tahun 1930 Bisri Mustofa diperintahkan untuk kembali lagi ke Kasingan untuk belajar mengaji dan mondok pada kyai Cholil. Bisri Mustofa kemudian dipasrahkan oleh ipar kyai Cholil yang bernama Suja'i. beliau terlebih dahulu belajar mengaji kepada Suja'i. hal ini dilakukan selain Bisri Mustofa belum siap mengaji langsung kepada kyai Cholil juga untuk membuktikan kepada teman-temannya bahwa beliau akan mampu dan untuk mempersiapkan diri nantinya mengaji secara langsung kepada kyai Cholil (Zaenal, 2005:14)

pada tanggal 7 Rajab $1354 \mathrm{H}$. atau bertepatan dengan bulan Juni 1935 dilaksanakan sebuah akad nikah antara Bisri Mustofa dengan Ma'rufah binti kyai Cholil. Pada waktu itu Bisri Mustofa berusia 20 tahun dan Ma'rufah berusia 10 tahun. Bisri Mustofa menjadi menantu dari kyai Cholil (pengasuh pondok Kasingan), sehingga beliau harus ikut membantu mengajar kitab-kitab kepada para santri..

Tahun 1936 berangkatlah Bisri Mustofa ke Mekkah untuk ibadah haji tanpa bekal yang cukup. Menjelang rombongan haji pulang ke tanah air, Bisri Mustofa sedih teringat bahwa dirinya menjadi menantu seorang kyai dengan ilmu yang sangat pas-pasan. Sehingga bersama dua orang temannya, yaitu; Suyuthi Cholil dan Zuhdi dari Tuban, Bisri Mustofa memutuskan bermukim untuk memperdalam ilmunya di Mekkah. Di sinilah Bisri Mustofa berguru pada kyai Bakir, Syaikh Umar Chamdan al Maghribi, Syekh Maliki, Sayyid Amin, Syekh Hasan Masysyat, Sayyid Alawi, dan kyai 'Abdul Muhaimin.

Tahun 1937 setelah Bisri Mustofa kembali dari Mekkah, maka tugas dan waktu mengajarnya semakin bertambah. Bisri Mustofa merasa puas atas pengajaran yang beliau sampaikan dapat mudah dipahami oleh para santri. Hal tersebut berjalan sampai satu setengah tahun. Kemudian datanglah musibah yang besar, yaitu pada tanggal Rabiusstani $1358 \mathrm{H}$. (1939 M.), mertua dan sekaligus gurunya yaitu Syaikhuna kyai Cholil wafat. Selanjutnya tanggung jawab mengurus Pesantren menjadi tanggung jawabnya.

Hasil karya KH Bisri Mustofa umumnya mengenai masalah keagamaan yang meliputi berbagai bidang di antaranya; Ilmu Tafsir dan Tafsir, Ilmu Hadis dan Hadis, Ilmu Nahwu, Ilmu Syaraf, Syari'ah atau Fiqih, Tasawuf/Akhlak, Aqidah, Ilmu Mantiq/Logika dan lain sebagainya. Kesemuanya itu berjumlah kurang lebih 176 judul Karya-karya KH Bisri Mustofa sebagai mana di atas, pada umumnya ditujukan pada dua kelompok sasaran. Pertama; kelompok santri yang sedang belajar di Pesantren. Biasanya karya-karyanya berupa ilmu Nahwu, ilmu Sharaf, ilmu Mantiq dan ilmu Balaghah. Kedua; kelompok masyarakat umum di pedesaan yang giat dalam pengajian di Surau atau Langgar, dalam hal ini karya-karyanya lebih banyak berupa ilmu-ilmu praktis yang berkaitan dengan ibadah dan akhlak.

Seminggu sebelum Wafat, pada tanggal 2 Pebruari 1977, KH Bisri Mustofa menghadiri pengajian di Kragan Rembang. tanggal 5 Pebruari 1977, beliau berada di Gedung Olahraga Semarang Jawa Tengah berpidato dalam Harlah PPP (Partai Persatuan Pembangunan). Sehari kemudian pergi ke Jakarta mengurus keberangkatan putranya yaitu; M. Adib Bisri ke Arab Saudi yang akan melanjutkan studi ke Riyadh. Selain itu beliau juga menyelesaikan beberapa urusan dengan Majelis Syuro PPP. Sepulangnya dari Jakarta, pada tanggal 10 Pebruari beliau langsung pergi ke Purwodadi, Grobogan. Dalam kondisi sakit beliau tetap memaksakan diri untuk mengajar di Pesantren. Sehabis mengajar santri-santrinya, yaitu pada tanggal 11 Pebruari KH Bisri Mustofa pergi ke Jombang untuk suatu urusan dengan Rais 'Am PBNU KH M. Bisri Syamsuri.

KH Bisri Mustofa wafat pada hari Rabu tanggal 17 Pebruari 1977 (27 Shafar 1397 H.), menjelang Asar di Rumah Sakit Umum Dr. Karyadi Semarang karena serangan jantung, tekanan darah tinggi dan gangguan pada paru-paru. Tidak ada tanda-tanda bahwa KH Bisri Mustofa akan wafat. beberapa orang yang dekat beliau mengatakan bahwa dibanyak kesempatan pidato dakwahnya pada hari-hari terakhir beliau banyak mengulas soal ukhrowi lebih dari biasanya. Sepulang dari Jombang, beliau benar-benar jatuh sakit.

Tanggal 14 Pebruari 1977 beliau harus diopname di Rumah Sakit Dr. Karyadi Semarang. Tetapi keadaan sudah terlambat, komplikasinya demikian berat sehingga detak jantung dan paru-parunya sudah tidak normal lagi. Dalam keadaan sakit itu KH Bisri Mustofa 
diketahui tidak pernah absen melaksanakan shalat fardhu walau pun dalam keadaan lemah sekali pun. Dokter sudah berusaha dengan maksimal untuk kesembuhan beliau. Tetapi Allah berkehendak lain, pada hari Rabu Pahing tanggal 17 Pebruari 1977 menjelang Asar KH Bisri Mustofa kembali ke Sang Maha Pencipta. Beliau wafat dengan tenang, dengan senyum dan wajah kemerahan tanda seseorang yang meninggal dengan Husnul Khatimah. Selepas Isya' jenazah dibawa ke Rembang diantar oleh Gubernur Jawa Tengah Supardjo Rustam serta tokoh-tokoh Jawa Tengah lainnya. Sepanjang jalan Semarang - Rembang, rakyat berderet di sepanjang jalan untuk memberikan penghormatan terakhir (Huda Zaenal A, 2005:58).

\section{Syi'ir Ngudi Susilo}

Kata atau istilah Syair berasal dari bahasa arab yaitu Syi'ir atau Syu'ur yang berarti "perasaan yang menyadari", kemudian kata Syu'ur berkembang menjadi Syi'ru yang berarti puisi dalam pengetahuan umum.(Al Munawwir : 2007). Kitab Syi'ir Ngudi Susilo merupakan kitab berbahasa Jawa dalam bentuk syair (puisi) yang terdiri dari 84 bait. Nama lengkap kitab tersebut adalah syi 'ir Ngudi Susilo Suko Pitedah Kanthi Terwelo, artinya Syair Belajar Akhlak yang memberi Petunjuk dengan Jelas. Buku yang berupa antologi "syi'iran" jelas berisi tentang pelajaran budi pekerti atau akhlak ini ditulis oleh KH. Bisri Mustofa pada akhir Jumadil Akhir 1373 H (tahun 1954 M). Kemudian kitab tersebut diterbitkan oleh Penerbit Menara Kudus, Kudus. Pada akhir syi 'ir Ngudi Susilo disampaikan jumlah bait yang terdapat dalam kitab ini yaitu 84 harapan dari KH Bisri Mustofa semoga semua cita-cita dan harapan dikabulkan Allah SWT dengan taufiq serta hidayah Nya baik didunia maupun diakhirat, Aamiin. (Bisri Mustofa, $\mathrm{tt}: 15$ )

\section{Konsep Pendidikan KH Bisri Mustofa}

K.H Bisri Mustofa dalam kitab Syi'ir Ngudi Susilo menekankan pentingnya pendidikan Akhlak sejak dini, dimulai dari lingkup keluarga, peran orang tua sangat dominan sebelum anak-anak berinteraksi dengan dilingkungan masyarakat. Pentingnya pelaksanaan nilai-nilai keagamaan dan pengamalan ibadah harus diperhatikan oleh orang tua, hal tersebut akan menjadi suatu Pembiasaan dalam kehidupan anak, beberapa konsep dan nilai-nilai pendidikan yang disampaikan K.H Bisri Mustofa antara lain :

Nilai Religius merupakan sikap dan perilaku patuh dalam melaksanakan ajaran agama yang dianutnya, toleran terhadap pelaksanaan ibadah agama lain, dan hidup rukun dengan pemeluk agama lain, ajak dan perintahkan kepadanya untuk melaksanakan shalat 5 Waktu, jika sudah masuk waktu pelaksanaanya,

"Yen wayahe sholat ojo tunggu perintah \# Enggal tandang cekat-ceket ojo wegah" (Ketika sudah waktunya Shalat jangan menunggu diperintah \# Segera laksanakan jangan malas) Hal ini selaras pula dengan Firman Allah dalam Q.S Thaha/20: 132 "dan perintahkanlah kepada keluargamu mendirikan shalat dan bersabarlah kamu dalam mengerjakannya. Kami tidak meminta rezki kepadamu, kamilah yang memberi rezki kepadamu. dan akibat (yang baik) itu adalah bagi orang yang bertakwa."

Anak merupakan amanat kedua orang tuanya, dan hatinya yang masih bersih merupakan permata yang sangat berharga. Jika ia dibiasakan untuk melakukan kebaikan, niscaya dia akan tumbuh menjadi baik dan menjadi orang yang bahagia di dunia dan akhirat. Sebaliknya, jika dibiasakan dengan keburukan serta ditelantarkan, niscaya dia akan menjadi orang yang celaka dan binasa. (Jamal Abdurrahman, 2000:16). Sesuai fitrahnya, anak senantiasa siap menerima yang baik atau yang buruk dari orang tua atau pendidiknya. Islam memberi pesan moral kepada orang tua berkaitan dengan pendidikan anak, dengan mendidik, mengarahkan dan memberi bekal akhlak sehingga mereka terbimbing menjadi anak yang membanggakan di hadapan Allah SWT.

KH Bisri Mustofa mengingatkan, latihlah anakmu untuk melaksankan shalat tepat pada waktunya agar tertanam kesadaran untuk beribadah. Proses pembelajaran hendaknya dilakukan dengan tekun tidak dengan bersenda gurau yang tidak ada manfaatnya, 
memperhatikan apa yang disampaikan Guru dengan seksama, sebagaimana syi'ir "ono kelas ojo ngantuk ojo guyon \# wayah ngaso keno ojo nemen guyon"(didalam kelas jangan mengantuk dan bergurau\#ketika istirahat jangan menambah gurauan). Al-Qur'an meganjurkan perilaku disiplin terhadap ketaatan pada peritah Allah SWT (Shalat) difirmankan dalam Q.S An-Nisa/4 : 103 "Maka apabila kamu telah menyelesaikan shalat(mu), ingatlah Allah di waktu berdiri, di waktu duduk dan di waktu berbaring. kemudian apabila kamu telah merasa aman, Maka dirikanlah shalat itu (sebagaimana biasa). Sesungguhnya shalat itu adalah fardhu yang ditentukan waktunya atas orang-orang yang beriman".

Penanaman nilai kedisiplinan harus ditanamkan kepada anak sejak kecil, sebagai pembiasaan dan perilaku dengan penuh kesadaran, tidak hanya bidang ibadah tetapi dalam bidang mu'amalah, ia akan tumbuh menjadi peribadi yang taat norma agama, masyarakat, bangsa dan negara.

Aktif kan Anak dengan kegiatan yang bermanfaat, hindarkan dari kemalasan, anak memiliki rasa ingin tahu dan suka berimajinasi, kedua sifat tersebut merupakan modal dasar bagi berkembangnya sikap atau berpikir kritis dan kreatif, kegiatan pembelajaran merupakan salah satu lahan yang harus diolah untuk meningkatkan sifat tersebut (Hamdani, 2011:106). Tuntun anak untuk aktif dalam kebaikan, sebagai mana yang terdapat dalam syi'ir "rampung sholat tandang gawe opo bahe \# kang prayogo koyo nyaponi omahe"(setelah selesai shalat lakukan segela sesuatu apa saja\#lebih utama seperti menyapu rumah), "Ono pamulangan kudu tansah gati \# Nompu piwulangan Ilmu kang wigati”(di tempat belajar senantiasa memperhatikan\#menerima pelajaran ilmu yang utama)

Syi'ir ini memberikan gambaran, betapa pentingnya melatih anak untuk senantiasa aktif dalam berbagai hal, terutama melatih mereka untuk memahami aktifitas yang merupakan perwujudan taat kepada Allah dan Rasul-Nya, berbakti kepada orang tua dan memperhatikan Guru dalam pembelajaran. Orang tua berperan mengarahkan mereka untuk aktif, dalam berbagai perilaku keagamaan, hal ini sesuai dengan firman Allah SWT dalam Q.S Al Insyirah/94 : 7 "Maka apabila kamu telah selesai (dari sesuatu urusan), kerjakanlah dengan sungguh-sungguh (urusan) yang lain.”.

Perilaku keagamaan adalah suatu pola keyakinan yang ditunjukkan seseorang pada kemampuan, perbuatan serta kebiasaan seseorang baik jasmani, rohani, emosional, dan sosial (Sukardi, Imam, 2003:122) Perilaku keagamaan dapat ditunjukkan dengan melakukan ibadah sehari-hari, berdoa, dan membaca kitab suci.( Hafidhuddin Didin, 2003:24) Pembentukan perilaku keagamaan Islam pada anak memerlukan dukungan dari berbagai pihak yaitu : (1) Lingkungan rumah merupakan tempat utama terbentuknya perilaku pada anak. Dalam pandangan psikologi pendidikan, diketahui lebih dari $70 \%$ perilaku anak itu adalah mirroring atau cermin langsung dari perilaku orang tua, dalam keseharian mendidik anak mereka. (2) Melibatkan orang tua dalam pembelajaran (sekolah) memberi dampak positif untuk waktu jangka panjang, maka sangatlah diperlukan peran orang tua untuk menumbuh kembangkan perilaku keagamaan anak.

Ke-Aktif-an anak dapat dilihat dari rasa peduli terhadap lingkungan, menjaga kelestarian, dan merawat agar tercipta lingkungan yang asri. dalam sya'ir "tekan omah nuli salin sandangane \#kudu pernah rajin rapi aturane"(sampai dirumah terus ganti pakaian\#harus rajin dan rapi penataanya). Lingkungan merupakan bagian dari integritas kehidupan manusia, sehingga lingkungan harus dipandang sebagai salah satu komponen ekosistem yang memiliki nilai untuk dihormati, dihargai, dan tidak disakiti, lingkungan memiliki nilai terhadap dirinya sendiri.

Integritas mempengaruhi perilaku manusia terhadap lingkungan disekitarnya. Integritas menumbuhkan tanggung jawab untuk berperilaku baik terhadap kehidupan di sekitarnya. Kerusakan alam diakibatkan dari sudut pandang manusia yang anthroposentris, memandang bahwa manusia adalah pusat dari alam semesta. Sehingga alam dipandang sebagai objek yang dapat dieksploitasi, hanya untuk memuaskan keinginan manusia, hal ini 
telah diingatkan oleh Allah SWT dalam Al Quran surah Ar Ruum /30:41: " telah nampak kerusakan di darat dan di laut disebabkan karena perbuatan tangan manusi, supay Allah merasakan kepada mereka sebahagian dari (akibat) perbuatan mereka, agar mereka kembali (ke jalan yang benar)."

Menanamkan kepedulian dapat diwujudkan dengan arahan dan teladan, bahwa alampun membutuhkan kasih sayang dan rasa aman. Manusia diciptakan untuk menjadi rahmat bagi seluruh alam, sebagaimana Allah telah berfirman dalam Q.S Al Anbiya'/21: 107, "dan Tiadalah Kami mengutus kamu, melainkan untuk (menjadi) rahmat bagi semesta alam". Mandiri adalah buah dari keaktifan dalam bertindak, dalam syi/ir KH Bisri Mustofa mengingatkan "kito iki bakal tininggal wong tuwo \# ora keno ora kito mesthi muwo"(kita ini pasti akan ditinggal orang tua\#mau tidak mau kita akan menjadi tuwa , "lamun kito podho katekan sejane \# ora liwat siro kabeh pemimpine".( jika kita mampu menggapai keinginan\#tidak menutup kemungkinan kamu semua akan menjadi pemimpinya)

Pendidikan Islam mengajarkan untuk mendidik anak secara mandiri, dengan mengatur anak secara jarak jauh.(Majid Abdul,1994:79) Ketika islam mewasiatkan pada orang tua untuk memelihara dan membimbing pendidikan anak-anaknya, Islam tidak bermaksud memporak-porandakan jiwa anak dalam jangka pendek maupun jangka panjang, sehingga hidup dan urusannya hanya dipikirkan, diatur dan dikelola oleh kedua orang tuanya.

Jujur Dalam konteks Islam disebut shiddiq. Dari segi bahasa shiddiq bisa berarti: 1) yang suka pada kebenaran, 2) yang membuktikan ucapannya dengan perbuatan, 3) yang berbakti serta selalu mempercayai (Munawir, 1997:770). jujur perkataannya selalu dapat dibuktikan dengan perilakunya. Apa yang dikatakannya sesuai dengan yang dipraktikkannya. Dalam pembinaan sikap jujur perlu pembiasaan, anak yang dibiasakan dengan kejujuran akan terbiasa dengan kejujuran, dan sebaliknya anak yang terbiasa dengan kebohongan akan terbiasa dengan kebohongan. "Wahid Hasyim santri pondok gak sekolah \# dadi mentri karo liyan ora kalah"(Wahid Hasyim seorang santri yang tidak sekolah\#Ia menjadi meteri tidak kalah dengan yang lainya/keilmuanya), "kabeh mau gumantung ing sejo luhur \# kanthi ngudi ilmu sarto laku jujur"'(semua itu tergantung pada keinginan yang luhur\#dengan menuntut ilmu dan berperilaku yang jujur).firmankan Allah dalam Q.S Attaubah, 9:119 "Hai orang-orang yang beriman bertakwalah kepada Allah, dan hendaklah kamu bersama orang-orang yang benar."

Inovasi merupakan suatu perubahan yang baru menuju ke arah perbaikan, yang lain atau berbeda dari yang ada sebelumnya, dilakukan dengan sengaja dan berencana. Inovasi ialah suatu perubahan yang baru dan bersifat kualitatif, berbeda dari hal yang ada sebelumnya serta sengaja diusahakan untuk meningkatkan kemampuan dalam rangka pencapaian tujuan tertentu dalam pendidikan. Istilah perubahan dan pembaruan ada perbedaan dan persamaannya. Perbedaannya, kalau pada pembaruan ada unsur kesengajaan. Persamaannya yakni sama-sama memiliki unsur yang baru atau lain dari sebelumnya.( Ihsan, F, 2003:76). Pembaharuan dan perubahan disampaikan KH Bisri Mustofa dalam sya'irnya : "Anak islam iki mongso kudu awas \# Ojo nganti leno mengko mundak tiwas"'(Anak islam pada saat ini harus waspada \# jangan sampai terlena akan berakibat celaka, "Anak islam kudu cita-cita luhur\#Keben dunya akhirate bisa makmur" (Anak Islam harus memiliki cita-cita luhur \# agar mencapai kemakmuran kehidupan dunia dan akhirat).

Dalam syi'ir ini dijelaskan bahwa Anak Islam (Generasi Islam) harus senantiasa cermat dalam menghadapi perkembangan Zaman, jangan terlena dengan keadaan tanpa melakukan perubahan ke arah kemajuan. Generasi islam harus memiliki cita-cita yang luhur agar memiliki peran dalam peradaban islam, hal ini akan terwujud apabila senantiasa berinovasi dan berkarya, tidak hanya berpangku tangan dengan perubahan yang ada. Hal ini selaras dengan firman Allah SWT dalam Q.S Ali Imron/3 : 190-191 "Sesungguhnya dalam penciptaan langit dan bumi, dan silih bergantinya malam dan siang terdapat tanda-tanda bagi orang-orang yang berakal, (190). (yaitu) orang-orang yang mengingat Allah sambil berdiri atau duduk atau dalam keadan berbaring dan mereka memikirkan tentang penciptaan 
langit dan bumi (seraya berkata): "Ya Tuhan Kami, Tiadalah Engkau menciptakan ini dengan sia-sia, Maha suci Engkau, Maka peliharalah Kami dari siksa neraka.(191)"

Jiwa inovatif akan menumbuhkembangkan ide-ide dan gagasan apabila disertai komunikasi yang baik dengan barbagai fihak, dengan orang tua, sanak saudara dan mitra kerja yang lain. seorang yang pandai harus menghargai sesama dan memahami akan kelebihan dan kekuranganya. "akeh bocah pinter nanging ora bagus \# budi pekertine sebab dho gemagus" (banyak anak pandai tetapi tidak baik\#budi pekertinya disebabkan kesombongan), "ring wong tuwo gak ngergani gak ngajeni \# sajak pinter dewe longko kang madhani"'(terhadapa orang tua tidak menghargai dan menghormati \# seakan-akan dia sendiri yang pandai tidak ada yang menandingi).

Imam al-Ghazali memberikan makna persahabatan adalah seseorang yang duduk bersama dan bercampur-gaul dengannya. tidak terjadi sebuah persahabatan antara manusia jika tidak didasari saling kasih-mengasihi. Persahabatan tersebut berasaskan budi baik dengan melakukan perbuatan yang baik sehingga terwujud sikap saling berkasih sayang (ulfah).(Al Ghozali, tt:108).

Nasionalisme sebagai suatu bentuk pemikiran dan cara pandang, yang menganggap bangsa sebagai bentuk organisasi politik yang ideal. Suatu kelompok manusia dapat disatukan menjadi bangsa karena unsur-unsur pengalaman sejarah yang sama, dalam arti pengalaman penderitaan atau kejayaan bersama.(Sumarsono, 1988:76) Indonesia adalah negara kesatuan (Unitaris) yaitu negara yang tidak tersusun dari beberapa negara, melainkan negara yang bersifat tunggal, artinya tidak ada negara dalam negara, dalam negara kesatuan hanya ada satu pemerintahan, yaitu pemerintahan pusat yang mempunyai kekuasaan tertinggi dalam segala tataran pemerintahan (Tim Dinas Pendidikan Prov Jateng, 2021:26). Cinta tanah Air dan bangsa sangat dianjurkan oleh KH Bisri Mustofa, bahkan beliau gigih dalam membela bangsa dan negara melalui berbagai perjuangan yang dilakukan, dalam syair beliau menyatakan, "Negaramu butuh menteri butuh mufti \# Butuh Qodhi pateh sten lan bupati"(Negaramu membutuhkan menteri, mebutuhkan mufti \# Membutuhkan Hakim, pateh sten dan bupati,"Butuh dokter butuh mester ingkang pinter \# Ilmu agama kang nuntun laku bener"'(Membutuhkan Dokter, Master yang pandai/Profesional\#Ilmu agama yang menuntun untuk berbuat kebenaran), "Sawang iku pengeran diponegoro \# Imam bonjol tengku umar kang kuncoro"(Lihatlah Pengeran Diponegoro\# Imam Bonjol, Teungku Umar yang terkenal), "Kebeh podo belo bongso lan negoro \# Podo ngagem daster pantes yen perwiro"(Semuanya membela bangsa dan Negara\#memakai Jubah sesuai sifat keperwiraan) Dalam syair dan ayat tersebut menjelaskan anjuran untuk cinta tanah air dengan senantiasa memohon agar negeri yang ditempati aman sentosa dan rezeki yang melimpah dengan ridho dari Allah SWT.

\section{PENUTUP}

KH Bisri Mustofa dalam Kitab Syi'ir Ngudi Susilo, menegaskan pentingnya penanaman karakter keimanan dan ketaqwaan kepada Anak dengan melaksanakan perintah-Nya, berperilaku sopan santun dan bertutur sapa yang baik kepada orang tua dan guru, merencanakan setiap kegiatan dengan pembagian waktu yang tepat, kegiatan belajar dilaksanakan dengan penuh konsentrasi, anjuran anak islam harus memiliki cita-cita luhur agar mencapai kehidupan yang sejahtera dunia akhirat. Secara umum konsep beliau dirangkum dalam istilah RAJIN yang merupakan singkatan dari Religius, Aktif, Jujur, Inovatif dan Nasionalis.

Implementasi konsep pendidikan karakter yang terdapat dalam kitab syi'ir ngudi susilo yaitu : (1) nilai-nilai Religiusitas di lakukan dengan : Shalat lima waktu, Membaca Al Qur'an, Bersyukur atas kenikmatan dari Allah SWT, Patuh dan taat terhadap guru; dan Menuntut Ilmu sejak kecil. (2) Meng-aktif-kan anak dengan berbagai kegiatan pembiasaan : Membantu orang tua, Bertutur sapa yang sopan dan taat pada kedua orang tua, Disiplin dalam kegiatan, mandiri, dan Menjaga kerukunan dan persaudaraan. (3) Menumbuh kembangkan ke-jujur-an 
dan tanggung jawab dengan tidak bermain tanpa ijin orang tua dan Berlaku adil terhadap sanak saudara. (4) Menjadikan anak kreatif dan inovatif, dengan berbagai pembiasaan: Waspada dan cermat terhadap perkembangan zaman, jangan mudah terpengaruh terhadap budaya non islam, Menyeimbangkan antara ilmu dan Akhlak, Optimis dalam menggapai citacita. (5) Jiwa Nasionalis anak bisa di tumbuh kembangkan melalui : penyajian kisah teladan tokoh, Rela berkorban mengisi kemerdekaan dengan belajar yang rajin dan tekun, Mempersiapkan diri dengan berbagai keahlian dan profesi untuk menjadi pemimpin bangsa, Membentengi diri dengan Ilmu Agama.

Konsep RAJIN (Religius, Aktif, Jujur, Inovatif, dan Nasionalisme) yang terdapat dalam kitab Syi'ir Ngudi Susilo karya KH Bisri Mustofa, sangat relevan untuk di jadikan rujukan pengembangan pendidikan nasional, konsep ini selaras dengan tujuan pendidikan yang tercantum dalam UU no 20 tahun 2003 tentang sistem Pendidikan Nasional, pada tujuan dan fungsi pendidikan yaitu berkembangnya potensi peserta didik agar menjadi Marusia yang beriman dan bertakwa kepada Tuhan Yang Maha Esa, berakhlak mulia, sehat, berilmu, cakap, kreatif, mandiri, dan menjadi warga negara yang demokratis serta bertanggung jawab, sehingga terwujud generasi yang tergolong ummat yang baik (Khaira Ummah).

Keluarga memiliki peran penting dalam pendidikan karakter anak, Anak adalah calon pemimpin, persiapkan diri demi masa depan dengan dasar keimanan dan ketaqwaan, berilmu pengetahuan dan keterampilan yang mempuni, dengan menghiasi hidup dengan akhlak yang terpuji sesuai tuntunan yang islami. Perbanyak kajian terhadap hasil karya Ulama' dan intelektual Indonesia, mereka lebih memahami karakter dan kearifan lokal budaya nasional indonesia, keteladanan, ketelatenan , kesungguhan dan keikhlasan para ulama dalam perjuanganya mencerdaskan kehidupan bangsa harus diapresiasi, dengan mengkaji, mempelajari dan melaksanakn fatwa-fatwanya, itulah yang menjadikan indonesia damai, rukun dalam kebhinekaan tercapai.

\section{DAFTAR PUSTAKA}

Abdul Majid Hasyim, Al-Husaini, Pendidikan Anak Menurut Islam. Bandung: Sinar Baru Algesindo. 1994

Abdurrahman, Jamal, Tahapan Mendidik Anak Teladan Rasulullah, Bandung: Irsyad Baitus Salam, 2000

Al-Ghazali, Abu Hamid, Ihya Ulum al-Din ,Bairut: Dar al-Fikr, 1989

Arikunto, Suharsimi, Prosedur Penelitian : suatu Pendekatan Paraktek, Bandung : Rineka Cipta, 2002.

Athol, Nathisul, Arif Fahrudin (edt), Hermeneutika Transendental: dari Konfigurasi Filosofis Menuju Praksis Islamic Studies, Yogyakarta: IRCiSoD, 2003.

Departemen Agama RI, Al-Qur'an dan Terjemahannya, Bandung: Lubug Agung, 1989

Kartono, Kartini ,Pengantar Metodologi Riset Sosial, Bandung: Rosdakarya,1996

Hadi, Sutrisno, Metodologi Research, Yogyakarta: Andi Ofset, 1997

Hafidhuddin, Didin, Islam Aplikatif. Jakarta: Gema Insani Press. 2003

Hamdani, Setrategi Belajar Mengajar ,Bandung : CV Pustaka Setia, 2011

Hamid, Hamdani \& Beni Ahmad Saebani. Pendidikan Karakter Perspektif Islam. Bandung: Pustaka Setia, 2013.

Ihsan, F. Dasar-dasar Kependidikan. Jakarta: Rineka Cipta, 2014

Marliani, Rosleny , Psikologi Perkembangan anak dan remaja, Bandung : Pustaka Setia, 2016

Munawwir, Ahmad Warson, Kamus Munawwir, Pustaka Pugressif, Surabaya 1997

Mustofa, Bisri, KH, Al Ibriiz lima'rifati tafsir Al Qur'an Al Aziz, Kudus : Menara Kudus, 1960. 
Pusat Kurikulum Departemen Pendidikan Nasional, Bahan Pelatihan Penguatan Metodologi Pembelajaran Berdasarkan Nilai-nilai Budaya untuk Membentuk Daya Saing dan Karakter Bangsa, Jakarta, 2010

Saptono. Dimensi-dimensi Pendidikan Karakter; Wawasan, Strategi, dan Langkah Praktis. Jakarta: Esensi Erlangga Group, 2011

Tafsir, Ahmad ,Ilmu Pendidikan dalam perspektif Islam, Bandung: Rosdakarya, 2011.

Tim Penyusun Buku Seri Sosialisasi Nasinalisme dan karakter bangsa, NKRI harga Mati Jayalah selamanya, Dinas Pendidikan Propinsi Jawa Tengah, 2012

UU no 20 Tahun 2003 tentang Sistem Pendidikan Nasional bab II pasal 3, Dasar, fungsi dan tujuan pendidikan Nasional

Zainal Huda, Ahmad, Mutiara Pesantren Perjalanan Khidmah K.H Bisri Mustofa Yogyakarta: LKIS, 2005.

Zubaedi, Desain Pendidikan Karakter, Konsep dan Aplikasinya dalam lembaga Pendidikan, Jakarta: Kencana, 2011 